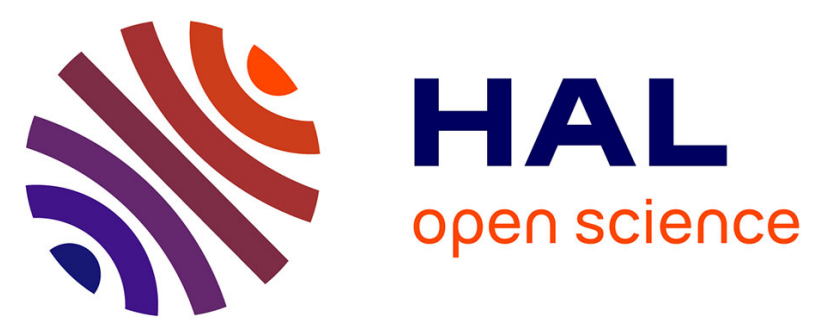

\title{
A kinetic resolution strategy for the synthesis of chiral octahedral NHC-iridium(III) catalysts
}

Romane Manguin, Delphine Pichon, Robert Tarrieu, Thomas Vives, Thierry

Roisnel, Vincent Dorcet, Christophe Crévisy, Karinne Miqueu, Ludovic

Favereau, Jeanne Crassous, et al.

\section{To cite this version:}

Romane Manguin, Delphine Pichon, Robert Tarrieu, Thomas Vives, Thierry Roisnel, et al.. A kinetic resolution strategy for the synthesis of chiral octahedral NHC-iridium(III) catalysts. Journal of the Chemical Society, Chemical Communications, 2019, 55 (43), pp.6058-6061. 10.1039/C9CC02434D . hal-02111808

\section{HAL Id: hal-02111808 \\ https://hal.science/hal-02111808}

Submitted on 7 May 2019

HAL is a multi-disciplinary open access archive for the deposit and dissemination of scientific research documents, whether they are published or not. The documents may come from teaching and research institutions in France or abroad, or from public or private research centers.
L'archive ouverte pluridisciplinaire HAL, est destinée au dépôt et à la diffusion de documents scientifiques de niveau recherche, publiés ou non, émanant des établissements d'enseignement et de recherche français ou étrangers, des laboratoires publics ou privés. 


\section{ChemComm}

\section{COMMUNICATION}

\section{A kinetic resolution strategy for the synthesis of chiral octahedral NHC-iridium(III) catalysts.}

Received 00th January 20xx, Accepted 00th January 20xx

DOI: $10.1039 / x 0 x \times 00000 x$
Romane Manguin, ${ }^{a+}$ Delphine Pichon, ${ }^{a+}$ Robert Tarrieu, ${ }^{a}$ Thomas Vives, ${ }^{a}$ Thierry Roisnel, ${ }^{b}$ Vincent Dorcet, ${ }^{\mathrm{b}}$ Christophe Crévisy, ${ }^{\mathrm{a}}$ Karinne Miqueu, ${ }^{\mathrm{c}}$ Ludovic Favereau, ${ }^{* \mathrm{~b}}$ Jeanne Crassous, ${ }^{\mathrm{b}}$ Marc Mauduit, ${ }^{a}$ and Olivier Baslé*a†

www.rsc.org/

The transmetalation reaction of a chiral-bidentate NHC-silver complex to racemic $\left[\operatorname{Ir}(\mu-\mathrm{Cl})(\mathrm{ppy})_{2}\right]_{2}$ operates with kinetic resolution leading to chiral octahedral NHC-iridium(III) complexes and enantio-enriched bis-cyclometalated iridium(III) complexes. The iridium(III) complexes demonstrated efficient catalytic activities in intermolecular [2+2] photocycloaddition reactions and in asymmetric Friedel-Crafts alkylations, respectively.

In the past two decades, bis-cyclometalated Iridium(III) complexes have been attracting broad interest due to their outstanding photophysical and chemical properties which are ideal in view of applications in photonic and optoelectronic devices, ${ }^{1}$ in bioimaging and cancer therapy as potential theranostic agents ${ }^{2}$ and in organic synthesis as photosensitizer and photoredox catalysts. ${ }^{3}$ More recently, particular attention has been given to $\mathrm{N}$-Heterocyclic Carbenes (NHCs) ligands in the design of highly stable luminescent cyclometalated iridium complexes with high range of emission colors. ${ }^{4}$ On the other hand, increasing efforts has been given to the development of efficient methods for the preparation of chiral octahedral $\operatorname{Ir}(\mathrm{III})$ complexes that are highly valuable materials to access selective protein inhibitors, circularly polarized (CP) lightemitting devices and chiral photocatalysts. ${ }^{5}$ Nevertheless, there is still a need for efficient and practical strategies to synthesize chiral non racemic luminescent NHC-based octahedral $\operatorname{Ir}(\mathrm{III})$ complexes. . $^{4 c, 1,6}$ Recently, we described a practical multicomponent strategy that provides access to various unsymmetrical $\mathrm{NHC}$ ligands precursors, including carboxyalkyl-NHCs that are beyond reach otherwise. ${ }^{7} \mathrm{NHC}$ ligands containing an additional donor functionality have demonstrated significant benefit in stabilizing a

a. Univ Rennes, Ecole Nationale Supérieure de Chimie de Rennes, CNRS, ISCR - UMR 6226, F-35000 Rennes, France.

b. Univ Rennes, CNRS, ISCR - UMR 6226, F-35000 Rennes, France.

c. CNRS/Univ Pau \& Pays Adour, Institut des Sciences Analytiques et de PhysicoChimie pour l'environnement et les Matériaux, IPREM, UMR 5254, Pau, cedex 09, 64053.

E-mail: olivier.basle@ensc-rennes1.fr

E-mail: ludovic.favereau@univ-rennes1.fr

† Present address: LCC-CNRS, Université de Toulouse, CNRS, UPS, Toulouse, France

E-mail: olivier.basle@lcc-toulouse.fr

+ These authors contributed equally to this work

Electronic Supplementary Information (ESI) available: [details of any supplementary information available should be included here]. See DOI: 10.1039/x0xx00000x variety of transition-metal complexes. ${ }^{8}$ Herein, we describe an efficient strategy for the synthesis of robust chiral luminescent octahedral NHC-iridium(III) complexes and enantio-enriched biscyclometalated iridium(III) complexes (Fig. 1). The catalytic potential of the new complexes was respectively demonstrated in a selective [2+2] photocycloaddition reaction and in asymmetric Friedel-Crafts alkylation.

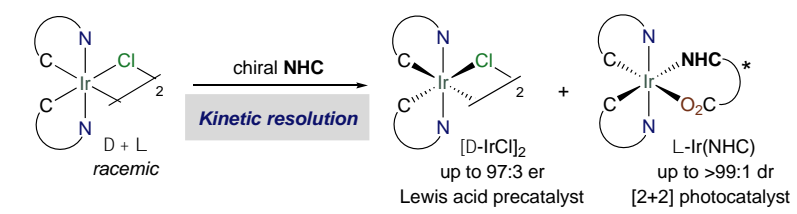

Fig. 1 Synthesis of chiral octahedral Iridium complexes.

The reaction of racemic $\left[\operatorname{Ir}(\mu-\mathrm{Cl})(\mathrm{ppy})_{2}\right]_{2}(\mathbf{1})$ with the chiral NHC$\mathrm{Ag}(S)-2$ complex in dichloromethane at $40{ }^{\circ} \mathrm{C}$ afforded a mixture of the $\Lambda-(S)$ and $\Delta-(S)$ diastereomers with a diastereomeric ratio of 2:1 in favor of the $\Lambda-(S)-3$ as determined by ${ }^{1} \mathrm{H}$ NMR spectroscopy (Scheme 1, Fig. S1, ESI ). The strong $\sigma$-donor ability and chelating coordination mode of the chiral NHC-carboxylate ligand conferred high complex stability, ${ }^{9}$ allowing efficient separation of the two diastereomers by silica gel chromatography to provide pure $\Lambda$-(S)3 and $\Delta-(S)-4$ in a good $75 \%$ combined isolated yields (49 and $26 \%$ respectively). Similar results were obtained when reacting racemic $\left[\operatorname{lr}(\mu-\mathrm{Cl})(\mathrm{ppy})_{2}\right]_{2}(\mathbf{1})$ with the chiral NHC-Ag $(R)-2$ complex of opposite configuration, affording the mirror-imaged diastereomeric pair which was isolated ( $80 \%$ yield) in about $2: 1$ ratio in favor of the $\Delta-(R)-3$. The absolute configuration at the metal center of the new octahedral NHC complexes was confirmed by X-ray diffraction analysis of single crystals (Fig. 2). Both $\Lambda-(S)-3$ and $\Delta-(S)-4$ diastereomers displayed strong structural similarity with high steric crowding around the Ir center. A typical ligand arrangement is observed with the pyridine $\mathrm{N}$ atoms of the ppy ligands lying in trans to each other, whereas the two ortho-carbons are respectively in trans to the carbenic carbon and in trans to the carboxylate fragment of the $\mathrm{NHC}$ ligand. The main structure difference results from the isobutyl substituent of the asymmetric carbon center that induces enhanced steric constraints in the $\Delta-(S)$ conformation by pointing towards the pyridyl ligand. 

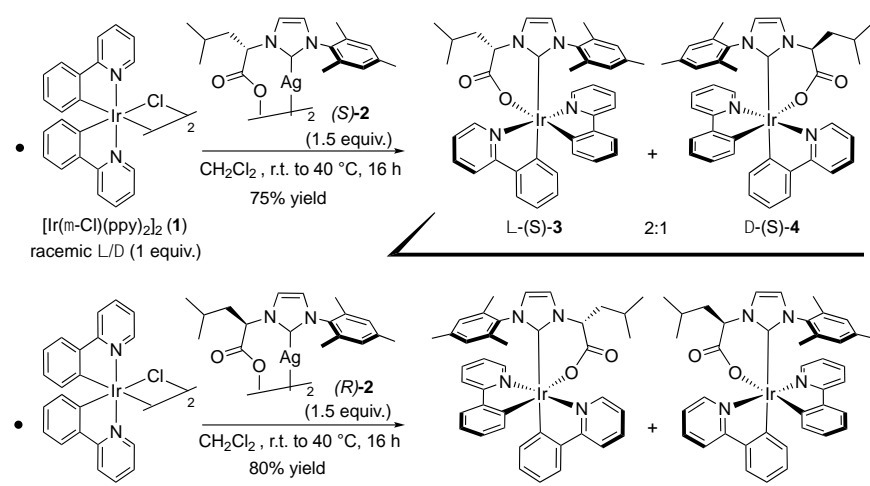

$\left[\operatorname{lr}(-\mathrm{Cl})(\mathrm{ppy})_{2}\right]_{2}(\mathbf{1})$ racemic $/$ (1 equiv.)

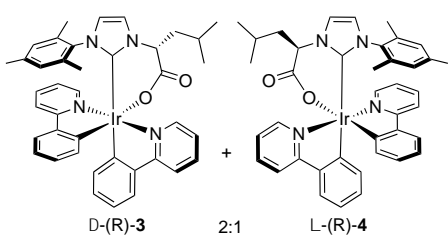

Scheme 1 Synthesis of $\Lambda-(S)-3$ and $\Delta-(S)-4$ diastereomers or $\Delta-(R)-3$ and $\Lambda-(R)-4$ diastereomers.

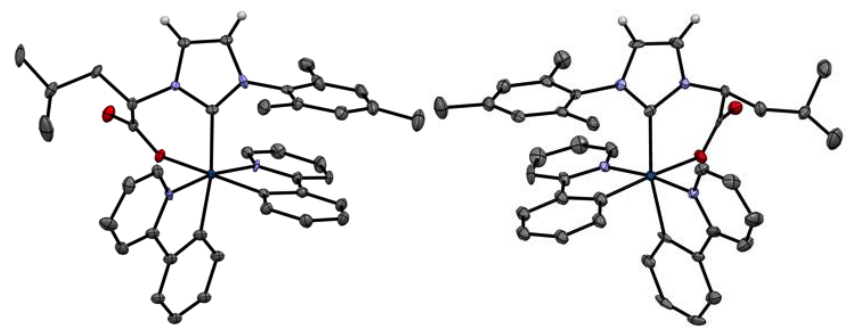

Fig. 2 Molecular structure of $\Lambda$-(S)-3 (left) and $\Delta-(S)-4$ (right)

(Chiro)optical properties of $\Lambda-(S)-3$ and $\Delta-(S)-4$ and their corresponding enantiomers $(\Lambda-(R)-3$ and $\Delta-(R)-4)$ are depicted in Figures 3 and S23. Similar UV-vis absorption spectra were recorded for all the iridium complexes, displaying intense transitions centered at $267 \mathrm{~nm}\left(\varepsilon \sim 26000 \mathrm{M}^{-1} \mathrm{~cm}^{-1}\right)$ and between 375 and $470 \mathrm{~nm}\left(\varepsilon \sim 2900 \mathrm{M}^{-1} \mathrm{~cm}^{-1}\right)$, attributed to Ligandcentered $\pi-\pi^{*}$ and Metal-to-Ligand / Ligand to Ligand Charge Transfer (MLCT / LLCT) transitions, respectively. ${ }^{10}$ Electronic Circular Dichroism (ECD) spectra show expected mirror-image spectra for each pair of enantiomers with similar responses above $260 \mathrm{~nm}$ for the diastereomer complexes (Figure 3). For instance, $\Delta^{-}$ (S)-4 displays a positive signal at $293 \mathrm{~nm}\left(\Delta \varepsilon=+6 \mathrm{M}^{-1} \mathrm{~cm}^{-1}\right)$, a set of three negative bands at 315,344 and $363 \mathrm{~nm}(\Delta \varepsilon=-12,-8.9$ and $-7.9 \mathrm{M}^{-1} \mathrm{~cm}^{-1}$, respectively) and a weaker positive signal at $445 \mathrm{~nm}$ $\left(\Delta \varepsilon=+6 \mathrm{M}^{-1} \mathrm{~cm}^{-1}\right)$. In the high energy region $(230-260 \mathrm{~nm})$, the impact of the carbene ligand chirality is clearly seen since $\Delta-(S)$ 4 exhibits a unique negative signal at $257 \mathrm{~nm}\left(\Delta \varepsilon=-19 \mathrm{M}^{-1} \mathrm{~cm}^{-1}\right)$ while $\Delta-(R)-4$ displays a very weak signature with successively positive and negative signals $\left(\Delta \varepsilon \sim-5 \mathrm{M}^{-1} \mathrm{~cm}^{-1}\right)$, which presumably result from the different orientation of the isobutyl substituent towards the phenyl pyridine ligand (Fig. 2). This is in agreement with TD-DFT calculations, performed at the B3LYP/SDD+f(Ir),6$31 \mathrm{G}^{* *}$ (other atoms) level of theory by taking into account solvent effect $\left(\mathrm{CH}_{2} \mathrm{Cl}_{2}\right)$ by a SMD solvent model, which also showed similar calculated ECD spectra in the $300-500 \mathrm{~nm}$ region and different signatures in the high-energy domain (see Figure S21, ESI). In terms of emission properties, $\Lambda-(S)-3$ and $\Delta-(S)-4$ exhibited similar unstructured phosphorescence spectra at room temperature centered at $508 \mathrm{~nm}$, characterized by a lifetime of around $1 \mu \mathrm{s}$ (Table S1 and Fig. S18, ESI). Circularly polarized luminescence $(\mathrm{CPL})$ was also recorded for these complexes, which exhibited opposite CPL responses for $\Lambda-(S)-3$ and $\Delta-(S)-4$, with an estimated glum factor of $1.5 \times 10^{-3}$ (Fig. S19). From these characterizations, it is interesting to note that the chiroptical properties of both the fundamental and excited states of the complexes are mainly dominated by the configuration of the iridium center and that the lateral asymmetric carbon center seems not to play a major role on the electronic and photophysical properties. This was also observed in the vibrational circular dichroism (VCD) spectra which displayed similar strong positive-negative signature at 1478-1474 $\mathrm{cm}^{-1}$ for the two diastereoisomers with $\Lambda$ stereochemistry at Ir center while differences in the $1200-1400 \mathrm{~cm}^{-}$ ${ }_{1}^{1}$ region were found for the diasteroisomers with the same $R$ or $S$ asymmetric carbon (see Fig. S23-S24 for experimental spectra and Fig. S25-26 for theoretical ones, ESI). Furthermore, cyclic voltammetry of $\Lambda-(S)-3$ and $\Delta-(S)-4$ displayed similar redox activity, with redox potentials of ca. $+0.9 \mathrm{~V}$ and $-2.1 \mathrm{~V}$ vs. SCE for the oxidation and reduction of both diasteroisomers.

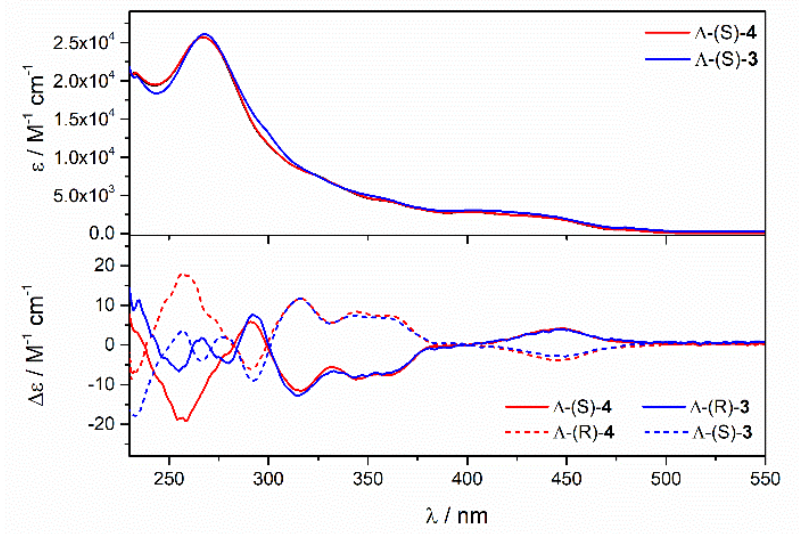

Fig. 3 UV-vis absorption spectra of $\Lambda$-(S)-3, $\Delta$-(S)-4. Electronic circular dichroism spectra of the 4 diastereomers $\Lambda-(S)-3, \Delta-(S)-4$ and $\Lambda-(R)-3, \Delta-(R)-4$.

In some instances, Meggers and co-workers observed diastereoselectivity when racemic $\mu$-dichloro-bridged iridium(III) dimers were treated with amino-acids or chiral salicyloxazoline ligand, and evidenced that this selectivity resulted from different solubility or thermal stability of the two diastereomers. ${ }^{11}$ However, in our case, both $\Lambda-(S)-3$ and $\Delta-(S)-4$ diastereomers display high solubility and high thermal stability under the standard conditions $\left(\mathrm{CH}_{2} \mathrm{Cl}_{2}, 2.10^{-2} \mathrm{M}, 40^{\circ} \mathrm{C}\right)$. Importantly, upon heating $\Delta-(S)-4$ for 2 days under these conditions, neither decomposition nor conversion to $\Lambda$ - $(S)-3$ could be detected, that excluded dynamic resolution of final products under thermodynamic control. ${ }^{12,13}$ In order to gain insights into the factors governing the diasteroselectivity observed, we performed the transmetalation reaction of a sub-stoichiometric amount of silver complex $(S)-2$ with racemic $\left[\operatorname{Ir}(\mu-\mathrm{Cl})(\mathrm{ppy})_{2}\right]_{2}(\mathbf{1})$ (Scheme 2). At room temperature, the $\Lambda$ isomer of racemic $[\operatorname{lr}(\mu-$ $\left.\mathrm{Cl})(\mathrm{ppy})_{2}\right]_{2}$ reacted spontaneously with $1 / 2$ equivalent of $(S)-2$ to form selectively $\Lambda-(S)-3$ as a single diastereomer together with the unreacted enantio-enriched $\Delta-(\mathrm{Cl})-1$ in high 97:3 er. The latter was further reacted in situ with silver acetylacetonate to yield the enantio-enriched $\Delta$-(acac)-5 complex with full retention of configuration at the metal center. In the same way, the kinetic resolution of the racemic $\left[\operatorname{lr}(\mu-\mathrm{Cl})(\mathrm{ppy})_{2}\right]_{2}(\mathbf{1})$ using $1 / 2$ equivalent of the silver complex $(R)-2$ afforded $\Delta-(R)-3$ as a single diastereomer and the enantio-enriched $\Lambda$ - $(\mathrm{Cl})-1$ in high 97:3 er, which was subsequently converted to the $\Lambda$-(acac) -5 with full retention of configuration. 

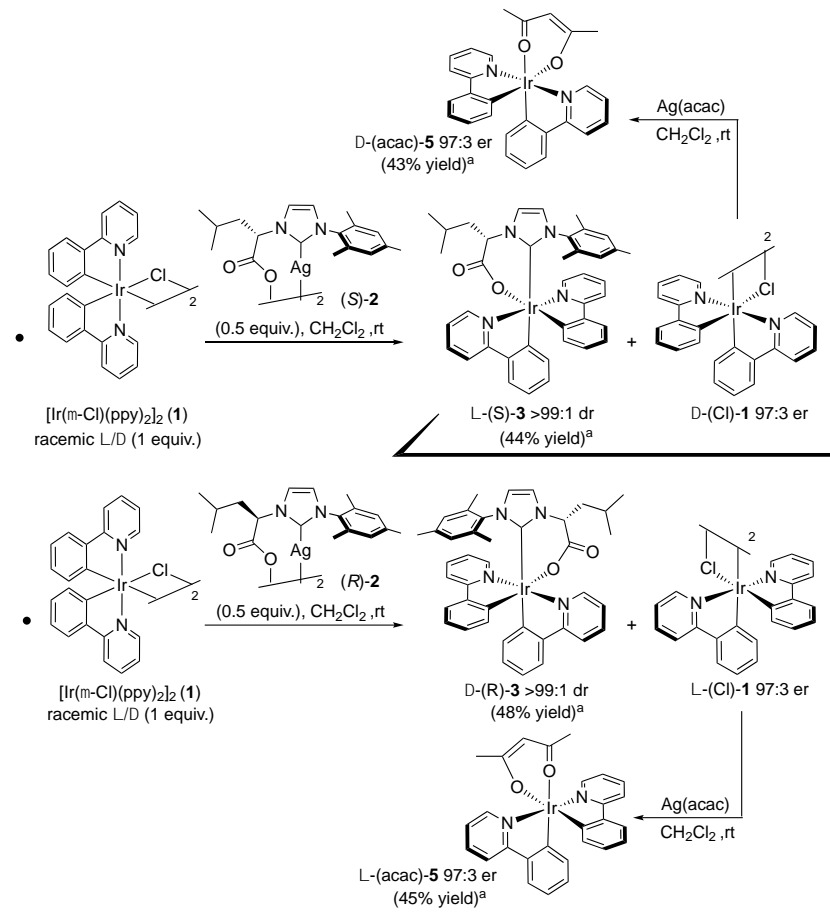

Scheme 2 Kinetic resolution of racemic $\left[\operatorname{Ir}(\mu-\mathrm{Cl})(\mathrm{ppy})_{2}\right]_{2}(\mathbf{1})$

On the basis of the above results, the proposed mechanism for the transmetalation reaction with kinetic resolution using (S)-2 and rac-1 is described in Scheme 3. For steric reasons, the approach of the NHC-Ag complex (S)-2 and interaction with the $\Lambda$-Cl complex is kinetically favored leading to the selective formation of the $\Lambda-(S)$ 3 complex. On the other hand, once all $\Lambda-(\mathrm{Cl})-\mathbf{1}$ is consumed, the mismatched pairing between $(S)-2$ and $\Delta-(\mathrm{Cl})-1$ can ultimately lead to the $\Delta-(S)$-intermediate with the isobutyl substituent of the asymmetric carbon center pointing towards the pyridyl ligand and undergo transmetalation from the pentavalent metal center to form the more sterically constrain $\Delta-(S)-4$ diastereomer. ${ }^{14}$ We therefore postulated that the initially observed diastereoselectivity $(\sim 2: 1 \mathrm{dr})$, is the result of kinetic resolution together with partial decomposition of the $\Delta-(S)$ intermediate under the standard reaction conditions (Scheme 1). ${ }^{15}$

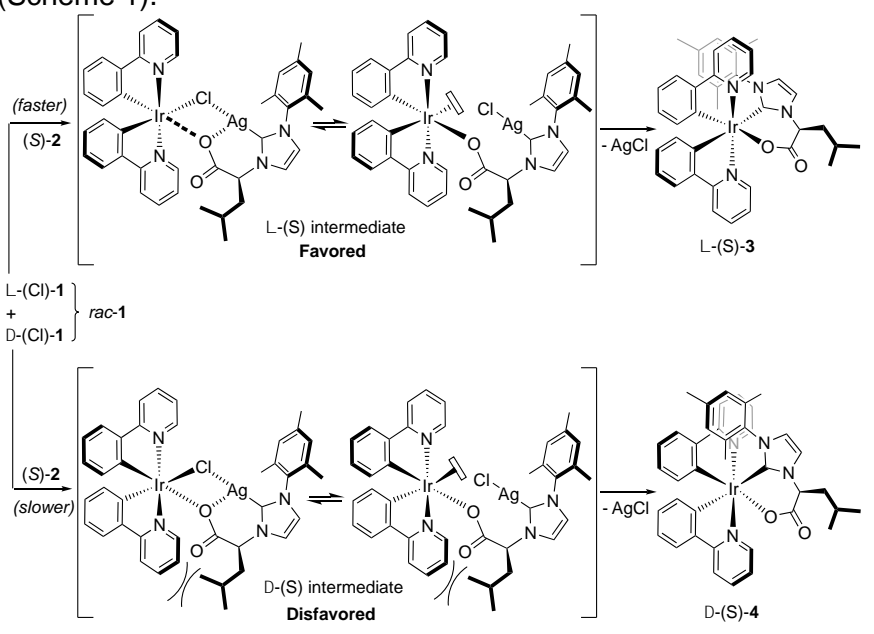

Scheme 3. Proposed mechanism for kinetic resolution with (S)-2.

The photophysical data demonstrated that complexes $\Lambda$-(S)-3 and $\Delta-(S)-\mathbf{4}$ could be considered as potential photocatalysts (see
ESI for details). Notably, their ability to generate relatively long and high energy triplet excited state $\left(E^{\top}=58.8 \mathrm{kcal} \mathrm{mol}^{-1}\right.$, see $\left.E S I\right)$ upon visible light excitation prompted us to evaluate them as photocatalysts in intermolecular [2+2] cycloaddition reaction involving energy transfer with judiciously selected substrates. ${ }^{16}$ Interestingly, irradiated with blue LEDs $\left(\lambda_{\max }=460 \mathrm{~nm}\right)$ at room temperature, $1 \mathrm{~mol} \%$ of the diastereomer $\Lambda-(S)-3$ or $\Delta-(S)-4$ demonstrated high efficiency in the cross [2+2] photocycloaddition of cinnamic acid $\left(7, \mathrm{E}^{\top} \sim 57.4 \mathrm{kcal} \mathrm{mol}^{-1}\right)^{17}$ and 1,1diphenylethylene (8), providing the trans-cyclobutane adduct 9 in high yield and diastereoselectivity (>98:2) in racemic form (Scheme 4). ${ }^{18}$

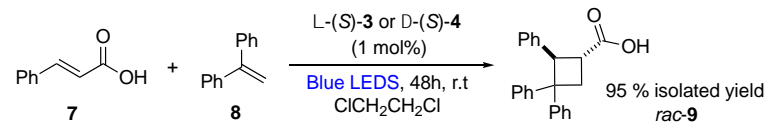

Scheme 4 Intermolecular [2+2] photochemical cycloaddition reaction

In the recent years, chiral Lewis acids that exclusively possess octahedral metal centrochirality have demonstrated efficiency in a variety of asymmetric transformations. ${ }^{19}$ The strategy of auxiliarymediated synthesis of substitutionally inert bis-cyclometalated iridium(III) complexes developed by Meggers and coworkers involves the traceless remove of the chiral auxiliaries (e.g. salicycloxazoline, amino acids) with retention of the absolute configuration at the metal under acidic conditions. ${ }^{20}$ In our particular case, $\Lambda-(S)-3$ and $\Delta-(S)-4$ demonstrated high stability under acidic conditions preventing the chiral NHC-carboxylate ligand to be used as auxiliaries. Therefore, we decided to use the enantio-enriched $\left[\operatorname{lr}(\mu-\mathrm{Cl})(\mathrm{ppy})_{2}\right]_{2}(\Lambda(\mathrm{Cl})-\mathbf{1})(97: 3$ er) obtained from kinetic resolution (vide supra, Scheme 2) and to evaluate its potential as chiral Lewis acid precatalyst in asymmetric conjugate addition $(\mathrm{ACA}) .^{20}$ Pleasantly, the cationic complex prepared in situ using silver hexafluorophosphate, allowed excellent catalytic activities and good chiral induction in the ACA of indole (10) to $\alpha, \beta$-unsaturated acylimidazoles $\mathbf{1 1}$ to provide the desired Friedel-Crafts alkylation products 12 with up to 78:22 er (Scheme 5). These results demonstrated that despite the relatively small steric hindrance of the 2-phenylpyridine ligands, satisfactory chirality transfer could be generated allowing facial discrimination at the coordinated electrophilic alkene substrate. ${ }^{21}$

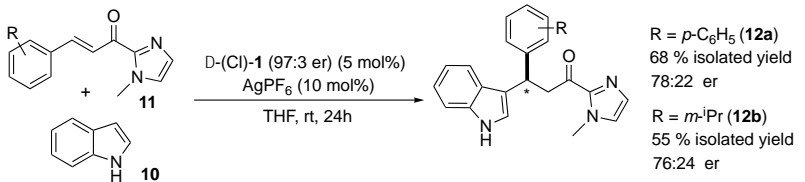

Scheme 5 Asymmetric Conjugate addition catalyzed by chiral Lewis acid.

In summary, we here reported the first example of asymmetric synthesis of chiral octahedral Iridium complexes bearing a chiral $\mathrm{NHC}$ ligand. The transmetalation reaction of a chiral-bidentate $\mathrm{NHC}$-silver complex to racemic $\left[\operatorname{Ir}(\mu-\mathrm{Cl})(\mathrm{ppy})_{2}\right]_{2}$ operates with kinetic resolution leading to enantio-enriched bis-cyclometalated iridium(III) and chiral NHC-based complexes. The latters $(\Lambda-(S)-3$ and $\Delta-(S)-4)$ display photophysical properties allowing them to be used as photocatalysts in intermolecular [2+2] cycloaddition. The enantio-enriched $\left[\Lambda \operatorname{lr}(\mu-\mathrm{Cl})(\mathrm{ppy})_{2}\right]_{2}(\Lambda-(\mathrm{Cl})-\mathbf{1}, 97: 3 \mathrm{er})$ demonstrated good efficiencies as chiral Lewis acid precatalyst in the enantioselective Friedel-Crafts addition of indole to $\alpha, \beta$ unsaturated acylimidazoles, and efforts to improve the selectivity outcomes of these transformations are underway in our laboratories. We believe that the here described synthetic 
approach will be of great use for the preparation of new transitionmetal based octahedral catalysts with considerable potential in a large variety of asymmetric transformations.

We acknowledge the CNRS, the ENSCR, the University of Rennes and the LCC. This work was supported by the ANR (ANR15-CE07-0012 "CHADOC" grant to OB), (ANR-16-CE07-0019 "Hel-NHC" grant to DP, MM, JC), the region Bretagne (ARED No. COH14007 "NHC-MET" grant to RT). JC thanks Thibault Reynaldo for VCD measurements. We acknowledge "the Direction du Numérique of the Université de Pau et des Pays de l'Adour" for the computing facilities, MCIA (Mesocentre de Calcul Intensif Aquitain) and CINES under allocation A005080045 made by Grand Equipement National de Calcul Intensif (GENCl).

\section{Conflicts of interest}

The authors declare no conflict of interest.

\section{Notes and references}

1 (a) Iridium(III) in Optoelectronic and photonics Applications (Ed.: E. Zysman-Colman), J. Wiley \& Sons Ltd, 2018; (b) A. F. Henwood and E. Zysman-Colman, Chem. Commun., 2017, 53, 807; (c) H. Xu, R. Chen, Q. Sun, W. Lai, Q. Su, W. Huang and X. Liu, Chem. Soc. Rev. 2014, 43, 3529.

2 H. Huang, S. Banerjee and P. J. Sadler, ChemBioChem, 2018, 19, 1574.

3 (a) M. H. Shaw, J. Twilton and D. W. C. MacMillan, J. Org. Chem. 2016, 81, 6898; (b) C. K. Prier, D. A. Rankic, D. W. C. MacMillan, Chem. Rev. 2013, 113, 5322.

4 (a) R. Visbal, M. C. Gimeno, Chem. Soc. Rev. 2014, 43, 3551; (b) I. Omae, Coord. Chem. Rev. 2016, 310, 154; (c) N. Hellou, M. Srebo-Hooper, L. Favereau, F. Zinna, E. Caytan, L. Toupet, V. Dorcet, M. Jean, N. Vanthuyne, J. A. Gareth Williams, L. Di Bari, J. Autschbach and J. Crassous, Angew. Chem. Int. Ed. 2017, 56, 8236; (d) P.-H Lanoë, J. Chan, G. Gontard, F. Monti, N. Armaroli, A. Barbieri, H. Amouri, Eur. J. Inorg. Chem. 2016, 1631; (e) F. Monti, M. G. I. La Placa, N. Armaroli, R. Scopelliti, M. Grätzel, M. K. Nazeeruddin and F. Kessler, Inorg. Chem. 2015, 54, 3031; (f) H. Na, A. Maity, R. Morshed, T. S. Teets, Organometallics, 2017, 36, 2965; (g) G. J. Barbante, E. H. Doeven, P. S. Francis, B. D. Stringer, C. F. Hogan, P. R. Kheradmand, D. J. D. Wilson and P. J. Barnard, Dalton Trans. 2015, 44, 8564; (h) C. Yang, F. Mehmood, T. L. lam, S. L.-F. Chan, Y. Wu, C.-S. Yeung, X. Guan, K. Li, C. Y.-S. Chung, C.Y. Zhou, T. Zou and C.-M. Che, Chem. Sci. 2016, 7, 3123; (i) P.-H. Lanoë, J. Chan, A. Groué, G. Gontard, A. Jutand, M.-N. Rager, N. Armaroli, F. Monti and A. Barbieri, H. Amouri, Dalton Trans., 2018, 47, 3440; (j) B. D. Stringer, L. M. Quan, P. J. Barnard, D. J. D. Wilson and C. F. Hogan, Organometallics, 2014, 33, 4860; (k) L.-H. Chung, H.-S. Lo, S.-W. Ng, D.-L. Ma, C.-H. Leung and C.-Y. Wong, Sci. Rep. 2015, 5, 15394; (I) A. Macé, N. Hellou, J. Hammoud, C. Martin, E. S. Gauthier, L. Favereau, T. Roisnel, E. Caytan, G. Nasser, N. Vanthuyne, J. A. G. Williams, F. Berrée, B. Carboni, J. Crassous, Helv. Chim. Acta 2019, doi.org/10.1002/hlca.201900044.

5 (a) C. Schaffner-Hamann, A. von Zelewsky, A. Barbieri, F. Barigelletti, G. Muller, J. P. Riehl and A. Neels, J. Am. Chem Soc. 2004, 126, 9339; (b) F. J. Coughlin, M. S. Westrol, K. D. Oyler, N. Byrne, C. Kraml, E. Zysman-Colman, M. S. Lowry and S. Bernhard, Inorg. Chem. 2008, 47, 2039; (c) L. Yang, A. von Zelewsky, H. P. Nguyen, G. Muller, G. Labat and H. StoeckliEvans, Inorg. Chim. Acta 2009, 362, 3853; (d) C.-H. Leung, H.J. Zhong, H. Yang, Z. Cheng, D. S. H. Chan, V. P.-Y. Ma, R. Abagyan, C.-Y. Wong and D. L. Ma, Angew. Chem. Int. Ed. 2012, 51, 9010; (e) E. Marchi, R. Sinisi, G. Bergamini, M. Tragni, M. Monari, M. Bandini and P. Ceroni, Chem. Eur. J.
2012, 18, 8765; (f) T.-Y. Li, Y.-M. Jing, X. Liu, Y. Zhao, L. Shi, Z. Tang, Y.-X. Zheng and J. L. Zuo, Sci. Rep. 2015, 5, 14912; (g) C. Citti, U. M. Battisti, G. Ciccarella, V. Maiorano, G. Gigli, S. Abbate, G. Mazzeo, E. Castiglioni, G. Longhi and G. Cannazza, J. Chromatogr. A, 2016, 1467, 335; (h) G. Mazzeo, M. FusH, G. Longhi, I. Rimoldi, E. Cesarotti, A. Crispini and S. Abbate, Dalton Trans. 2016, 45, 992; (i) T.-Y. Li, Y.-X. Zheng and Y.-H. Zhou, Dalton Trans. 2016, 45, 19234; (j) N. Hellou, C. JahierDiallo, O. Baslé, M. Srebo-Hooper, L. Toupet, T. Roisnel, E. Caytan, C. Roussel, N. Vanthuyne, J. Autschbach, M. Mauduit and J. Crassous, Chem. Commun. 2016, 52, 9243; (k) L. Zhang, E. Meggers, Acc. Chem. Res. 2017, 50, 320; (I) E. Meggers, Angew. Chem. Int. Ed. 2017, 56, 5668.

6 (a) Y. Tan, K. Harms and E. Meggers, Eur. Inorg. Chem. 2018, 2500. (b) Y. Li, M. Lei, W. Yuan, E. Meggers and L. Gong, Chem. Commun., 2017, 53, 8089.

7 (a) P. Queval, C. Jahier, M. Rouen, I. Artur, J.-C. Legeay, L. Falivene, L. Toupet, C. Crévisy, L. Cavallo, O. Baslé and M. Mauduit, Angew. Chem., Int. Ed., 2013, 52, 14103; (b) C. Jahier-Diallo, M. S. T. Morin, P. Queval, M. Rouen, I. Artur, P. Querard, L. Toupet, C. Crévisy, O. Baslé and M. Mauduit, Chem. - Eur. J., 2015, 21, 993; (c) R. Tarrieu, A. Dumas, J. Thongpaen, T. Vives, T. Roisnel, V. Dorcet, C. Crévisy, O. Baslé and M. Mauduit, J. Org. Chem. 2017, 82, 1880.

8 (a) E. Peris, Chem. Rev., 2018, 118, 9988; (b) R. Corberan, V. Lillo, J. A. Mata, E. Fernandez, and E. Peris, Organometallics 2007, 26, 4350 .

9 J. Thongpaen, T. E. Schmid, L. Toupet, V. Dorcet, M. Mauduit and O. Baslé, Chem. Commun. 2018, 54, 8202.

10 C.-H. Yang, J. Beltran, V. Lemaur, J. Cornil, D. Hartmann, W. Sarfert, R. Fröhlich, C. Bizzarri and L. De Cola, Inorg. Chem., 2010, 49, 9891.

11 M. Helms, C. Wang, B. Orth, K. Harms and E. Meggers, Eur. J. Inorg. Chem. 2016, 2896.

$12 \Lambda$-(S)-3 was found slightly lower in energy than $\Delta-(S)-4(\Delta G=$ $1.2 \mathrm{Kcal} / \mathrm{mol}$ ), see Fig. S33, ESI. For an example of dynamic resolution under thermodynamic control with ruthenium complexes, see: Z. Lin, L. Gong, M. A. Celik, K. Harms, G. Frenking and E. Meggers, Chem. Asian J. 2011, 6, 474.

13 For chiral transfer in coordination complexes see reviews: (a) J. Crassous, Chem. Soc. Rev. 2009, 38, 830; (b) J. Crassous, Chem. Comm. 2012, 48, 9684.

14 (a) P. J. Heard, Chem. Soc. Rev. 2007, 36, 551.

15 The reaction performed at $22{ }^{\circ} \mathrm{C}$ required 3 days for completion and a diastereomeric ratio of exactly $1: 1$ was observed.

16 (a) T. Lei, C. Zhou, M.-Y. Huang, L.-M. Zhao, B. Yang, C. Ye, H. Xiao, Q.Y. Meng, V. Ramamurthy, C.-H. Tsung and L.-Z. Wu, Angew. Chem. Int. Ed. 2017, 56, 15407; (b) S. K. Pagire, A. Hossain, L. Traub, S. Kerres and O. Reiser, Chem. Commun, 2017, 53, 12072. For a recent review, see: Q.-Q. Zhou, Y.-Q. Zou, L.-Q. Lu and W.-J. Xiao, Angew. Chem. Int. Ed. 2018, 58, 1586.

17 Y. Shioya and M. Yagi, J. Photochem. Photobiol. A. 1995, 86, 97.

18 To illustrate the challenge in developing enantioselective excited-state $[2+2]$ reactions controlled by chiral hydrogenbonding Iridium sensitizer, see: K. L. Skubi, J. B. Kidd, H. Jung, I. A. Guzei, M.-H. Baik and T. P. Yoon, J. Am. Chem. Soc. 2017, 139, 17186

19 (a) Z.-Y. Cao, W. D. G. Brittain, J. S. Fosseyb and F. Zhou, Catal. Sci. Technol. 2015, 5, 3441.

20 (a) M. Helms, Z. Lin, L. Gong, K. Harms and E. Meggers, Eur. J. Inorg. Chem. 2013, 4164; (b) J. Ma, X. Zhang, X. Huang, S. Luo and E. Meggers, Nature Protocols, 2018, 13, 605.

21 (a) H. Huo, C. Fu, K. Harms and E. Meggers, J. Am. Chem. Soc. 2014, 136, 2990; (b) X. Shen, H. Huo, C. Wang, B. Zhang, K. Harms, and E. Meggers, Chem. Eur. J. 2015, 21, 9720-9726. 